deficiency syndrome (AIDS): a problem of antibody specificity. J Clin Pathol 1987;40: 262-6.

2 Gown AM, Vogel AM. Monoclonal antibodies to intermediate filament proteins of human cells: unique and cross-reacting antibodies. $J$ Cell Biol 1982;95:414-24.

3 Heyderman E. Immunoperoxidase technique in histopathology: applications, methods, and controls. J Clin Pathol 1979;32:971-8.

4 Maciver AG, Mepham BL. Immunoperoxidase techniques and controls. J Clin Pathol 1980;33:1218-9.

\section{Zinc supplementation and erythropoiesis in the elderly}

Our previously reported group of geriatric patients with senile purpura, who proved to have low plasma zinc concentrations,' did not have obvious related haematological abnormalities. The haemoglobin concentrations, however, did lie at the lower end of the normal range established for normal younger adults. As falls in haemoglobin related to age have been found in several studies, including those reporting on healthy subjects where no underlying cause was found, ${ }^{2}$ we undertook a pilot study of serum zinc, erythropoietin, and androgen concentrations in addition to full blood counts in 10 men and 10 women aged between 65 and 95 years. They were attending a day hospital for social reasons and had no physical or biochemical evidence or disorders known to influence erythropoiesis. Serum erythropoiesis was measured using a modification of the fetal mouse liver cell bioassay. ${ }^{3}$ Zinc concentra- tions were obtained by atomic absorption spectrophotometry, and testosterone by radioimmunoassay.

The red blood cell counts and the haematocrit values following zinc supplementation were significantly improved for men $(p<0.025)$ but not for women ( $<<$ 0.80 and $p<0.60$, respectively). The other results are given in the table. The haemoglobin concentrations in women were in the lower half of the normal range, but those for men were significantly decreased as a group compared with the normal range. Three women and one man had high erythropoiesis values. This suggests that a decrease in erythropoiesis had been recognised by the body as a pathological process, and in an attempt to correct this the kidneys were stimulated to produce higher levels of erythropoiesis. Despite increased production of this hormone the haematological indices had not been completely corrected.

Reported declining concentrations of androgens in both men and women ${ }^{4}$ suggest that the relative lack of testosterone, and particularly its biologically active metabolites, may be responsible for decreasing erythropoiesis in the elderly. Lowered androgen concentrations may be decreasing the number of committed stem cells available to develop along the erythroid line, thus making the marrow relatively insensitive to increased erythropiesis concentrations. In addition, the concentration of erythropiesis induced when androgen concentration is lowered may not compensate the degree of disturbance in red cell production.

Studies have shown that whole body zinc concentrations decrease with age. ${ }^{5}$ Our correlation between zinc and testosterone values suggest that zinc may possibly be exerting an effect on erythropoiesis via androgen metabolism.

The results seen in this small pilot study of elderly subjects after three months of oral zinc supplementation are compatible with the hypothesis that there is a true anaemia of old age which may be related to lowered androgens, which in turn may be due to an lack of zinc. Clearly, investigations of larger numbers of aged subjects, particularly the concentrations of bound and free testos $\vec{F}$ terone, as well as the effect of its biologically? active metabolities at the various levels of the erythron pathway, may yield a clearer pic흠. ture of the underlying pathological process. $\frac{\bar{\omega}}{\widehat{Q}}$ NY HABOUBI $\stackrel{* D}{D}$ MA BAKERT OHB GYDE $†$ ( NA SMALL $\overrightarrow{0}$ NUHA HABOUBI $\neq$ * Department of Geriatric Medicine $\vec{\omega}$ Wrexham Maelor Hospital Croesnewydd Roas Wrexhami Clwy $\vec{\delta}$ L113 7TD †Department of Pathology유 East Birmingham Hospitalo Bordesley Green East, Birmingham B9 $5 S \overline{T_{C}}$

$\ddagger$ Department of Clinical Endocrinology Birmingham and Midland Hospital fo Women $\overrightarrow{00}$ Showell Green Lane Birmingham B11 $4 \mathrm{HE}$

References

1 Haboubi NY, Haboubi NAA, Gyde OHB Small NA, Barford AV. Zinc deficiency in senile purpura. J Clin Pathol 1985;38 1189-91.

2 Yip R, Johnson C, Sallman PR. Age-relate $\overrightarrow{\vec{S}}$ changes in laboratory values used in the diagnosis of anaemia and iron deficiency. AmJ Clin Nutr 1984;39:427-36.

3 Dunn CDR, Gibson L. Erythropoietin bio assays using fetal mouse liver cells: valida tions and technical improvements. Exp. Haematol 1983;11:590-600.

4 Shahidi NT. Androgens and erythropoiesis. $N$. Engl J Med 1973;286:72-80.

5 Wilson CWM, Myskow L. Reduced serum zinc levels and oral zinc supplementation in geriatric patients. Int J Vitam Nutr Res은 1985;55:331-6.

Table Haematological and biochemical results for elderly subjects before and after three months of oral zinc supplementation

\begin{tabular}{|c|c|c|c|c|c|c|c|c|}
\hline & & \multicolumn{3}{|l|}{ Before } & \multicolumn{3}{|l|}{ After } & \multirow{2}{*}{ p value } \\
\hline & & Mean & $95 \%$ CI of mean & Range & Mean & $95 \%$ CI of mean & Range & \\
\hline $\begin{array}{l}\mathrm{Hb}(\mathrm{g} / \mathrm{dl}) \\
\text { Erythropoiesis }(\mathrm{mIU} / \mathrm{ml}) \\
\text { Testosterone }(\mathrm{nmol} / \mathrm{l}) \\
\text { Zinc (umol/l) }\end{array}$ & $\begin{array}{l}\mathbf{F} \\
\mathbf{M} \\
\mathbf{F} \\
\mathbf{M} \\
\mathbf{F} \\
\mathbf{M} \\
\mathbf{F} \\
\mathbf{M}\end{array}$ & $\begin{array}{r}12.5 \\
13.5 \\
80.8 \\
69.0 \\
1.3 \\
10.6 \\
11.2 \\
11.7\end{array}$ & $\begin{array}{c}0.5 \\
1.22 \\
26 \cdot 6 \\
20.6 \\
0.3 \\
4 \cdot 06 \\
0.74 \\
1 \cdot 28\end{array}$ & $\begin{array}{l}11 \cdot 4-13 \cdot 7 \\
11 \cdot 1-15 \cdot 5 \\
25-169 \\
33-98 \\
0.6-2 \cdot 0 \\
0.7-16.0 \\
9.9-12.9 \\
9.9-14.7\end{array}$ & $\begin{array}{c}12 \cdot 9 \\
13 \cdot 8 \\
63 \cdot 2 \\
70 \\
1 \cdot 5 \\
14 \cdot 1 \\
16 \cdot 4 \\
15 \cdot 9\end{array}$ & $\begin{array}{c}0.46 \\
1 \cdot 12 \\
15 \cdot 16 \\
16 \cdot 2 \\
0 \cdot 32 \\
5 \cdot 22 \\
4 \cdot 2 \\
3 \cdot 58\end{array}$ & $\begin{array}{l}11 \cdot 9-14 \cdot 0 \\
11 \cdot 4-15 \cdot 5 \\
36-115 \\
32-99 \\
0 \cdot 6-2 \cdot 2 \\
1 \cdot 8-23 \cdot 5 \\
9 \cdot 6-31 \cdot 2 \\
10-21 \cdot 7\end{array}$ & $\begin{array}{l}0.110 \\
0.035 \\
0.041 \\
0.447 \\
0.060 \\
0.010 \\
0.025 \\
0.017\end{array}$ \\
\hline
\end{tabular}

